\title{
Molecular Modeling Studies on Carbazole Carboxamide Based BTK Inhibitors Using Docking and Structure-Based 3D-QSAR
}

\author{
Rui Li ${ }^{1}$, Yongli Du ${ }^{1, *}$, Zhipei Gao ${ }^{1}$ and Jingkang Shen ${ }^{2}$ \\ 1 School of Chemistry and Pharmaceutical Engineering, Qilu University of Technology (Shandong Academy \\ of Sciences), 3501 Daxue Road, Jinan 250353, China; 18364173762@163.com (R.L.); gaomills@163.com (Z.G.) \\ 2 State Key Laboratory of Drug Research, Shanghai Institute of Materia Medica, Chinese Academy of Sciences, \\ 555 Zu Chong Zhi Road, Shanghai 201203, China; jkshen@simm.ac.cn \\ * Correspondence: ylduyjs@163.com; Tel.: +86-0531-8963-1208; Fax: +86-0531-8963-1207
}

Received: 19 March 2018; Accepted: 9 April 2018; Published: 19 April 2018

\begin{abstract}
Rheumatoid arthritis (RA) is the second common rheumatic immune disease with chronic, invasive inflammatory characteristics. Non-steroidal anti-inflammatory drugs (NSAIDs), slow-acting anti-rheumatic drugs (SAARDs), or glucocorticoid drugs can improve RA patients' symptoms, but fail to cure. Broton's tyrosine kinase (BTK) inhibitors have been proven to be an efficacious target against autoimmune indications and B-cell malignancies. Among the current 11 clinical drugs, only BMS-986142, classified as a carbazole derivative, is used for treating RA. To design novel and highly potent carbazole inhibitors, molecular docking and three dimensional quantitative structure-activity relationship (3D-QSAR) were applied to explore a dataset of 132 new carbazole carboxamide derivatives. The established comparative molecular field analysis (CoMFA) $\left(q^{2}=0.761, r^{2}=0.933\right)$ and comparative molecular similarity indices analysis (CoMSIA) $\left(q^{2}=0.891, r^{2}=0.988\right)$ models obtained high predictive and satisfactory values. CoMFA/CoMSIA contour maps demonstrated that bulky substitutions and hydrogen-bond donors were preferred at $R_{1}$ and 1-position, respectively, and introducing hydrophilic substitutions at $\mathrm{R}_{1}$ and $\mathrm{R}_{4}$ was important for improving BTK inhibitory activities. These results will contribute to the design of novel and highly potent BTK inhibitors.
\end{abstract}

Keywords: rheumatoid arthritis (RA); Broton's tyrosine kinase (BTK); carbazole carboxamide derivatives; 3D-QSAR; comparative molecular field analysis (CoMFA); comparative molecular similarity indices analysis (CoMSIA)

\section{Introduction}

Rheumatoid arthritis (RA) is an autoimmune destructive disease by affecting the joints, causing progressive, symmetric, erosive destruction of cartilage and bone [1]. RA has affected about 24.5 million people as of 2015, and the condition newly develops in approximately $1 \%$ of the population each year [2]. Two main classes of traditional medications were used for treatment of RA: first-line drugs (involved non-steroidal anti-inflammatory drugs (NSAIDs) and corticosteroids) and second-line drugs (also referred to as disease-modifying anti rheumatic drugs or disease-modifying anti rheumatic drugs (DMARDs)) [3]. However, these two classes of medicine possess some serious side effects, such as increased susceptibility to bruising, abdominal pain, and even risk of infections and bleeding [4]. Therefore, it is increasingly crucial to develop novel drugs with improved efficacy and safety in RA treatment.

Broton's tyrosine kinase (BTK) is a member of the Tyrosine-protein kinase (TEC) kinase family and plays a critical role in the B-cell development and activation through mediating the downstream signaling cascade of B-cell receptors (BCRs) $[5,6]$. The increase in BTK expression can cause the chronic 
activation of the BCR signaling pathway, which affects B-cell proliferation and differentiation [7]. As a result, it can cause a lack of antibodies in the body, which finally gives rise to RA and other inflammatory diseases [8]. Therefore, inhibiting BTK activities to keep the normal function of the BCR signaling pathway is an effective way to treat RA. Recently, BTK inhibitors have been of increased interest in the clinical study of B-cell tumors and immune disease. Ibrutinib [8,9], acalabrutinib [10], ONO-4059 [11], spebtutinib [12], HM71224 [13], and BMS-986142 [14] have advanced into clinical trials, and their reported chemical structures are shown in Figure 1. As candidate drugs for treating RA, only BMS-986142 has advanced into Clinical Phase I with improved oral exposure, kinase selectivity, and high BTK potency [15]. Compared with NSAIDs and DMARDs, BMS-986142 has advantages of increased safety and efficacy as well as the less dependence on medication [16]. Therefore, exploring novel and highly potent BTK inhibitors for RA treatment is an important and promising prospect.

Here we report on molecular modeling studies performed by comparative molecular field analysis (CoMFA) [17] and comparative molecular similarity indices analysis (CoMSIA) [18] modules, as well as docking results, to investigate the three-dimensional quantitative structure-activity relationship (3D-QSAR) between carbazole inhibitors (BMS-986142 analogues) and BTK.

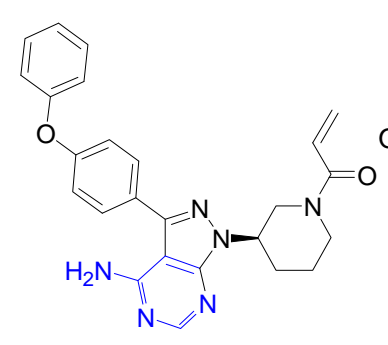

Ibrutinib $\mathrm{IC}_{50}=0.5 \mathrm{nM}$ launched

Celera/Pharmacyclics/Janssen

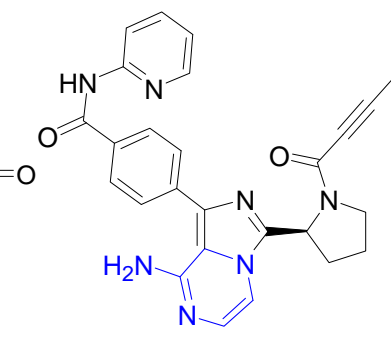

Acalabrutinib

$\mathrm{IC}_{50}=3.1 \mathrm{nM}$

Phase III

Acerta Pharmacyclics

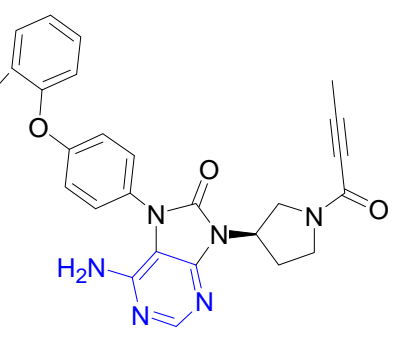

ONO-4059

$\mathrm{IC}_{50}=23.9 \mathrm{nM}$

PhaseII

Ono/Gilead

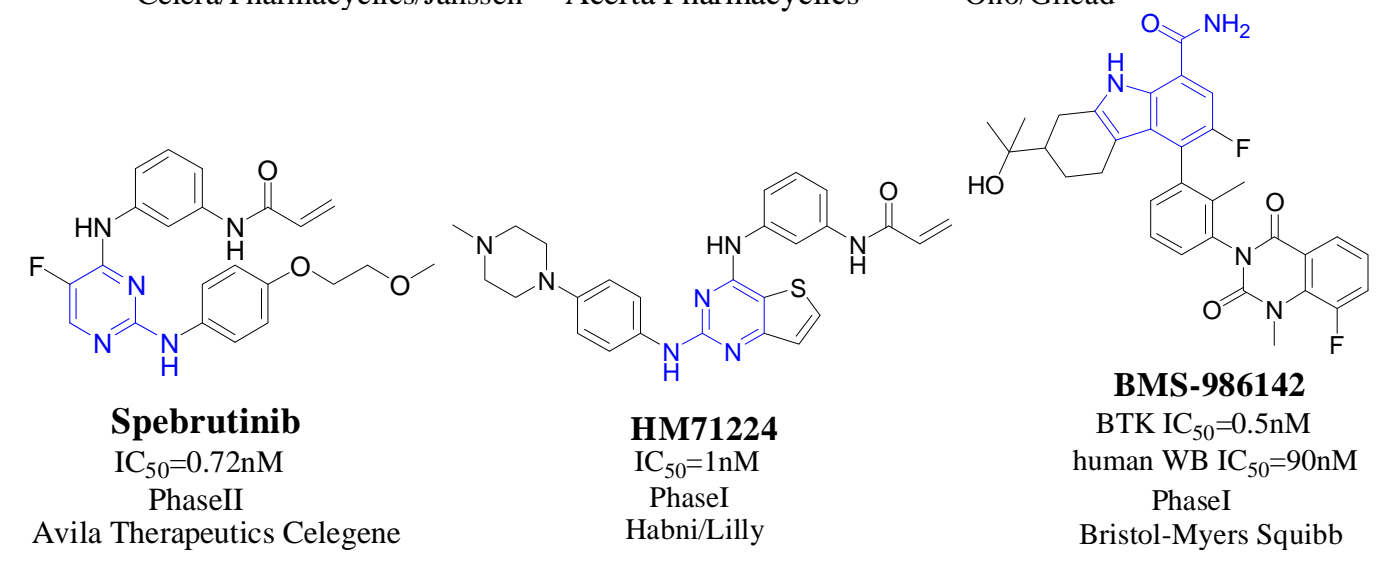

Figure 1. The chemical structures of several Broton's tyrosine kinase (BTK) inhibitors that have entered into clinical trials.

\section{Results and Discussion}

\subsection{Molecular Docking}

The aim of the molecular docking was to predict the binding affinity and interactions of carbazoles known to modulate the activity of BTK. The accuracy of the docking program was confirmed by comparing the predicted compound (76, green) and ligand (red) extracted from the crystal structure of BTK (Protein Data Bank ID: 5JRS). The result, revealing excellent agreement, is shown in Figure 2A and confirms that the selected experimental parameters and procedures used for molecular docking and alignment were reasonable. As depicted in Figure 2A, the common carbazole rings of $\mathbf{7 6}$ and $\mathbf{7 9}$ as 
well as experimental ligand were in the same position and mainly interacted with residues Glu475, Tyr476, and Met477.

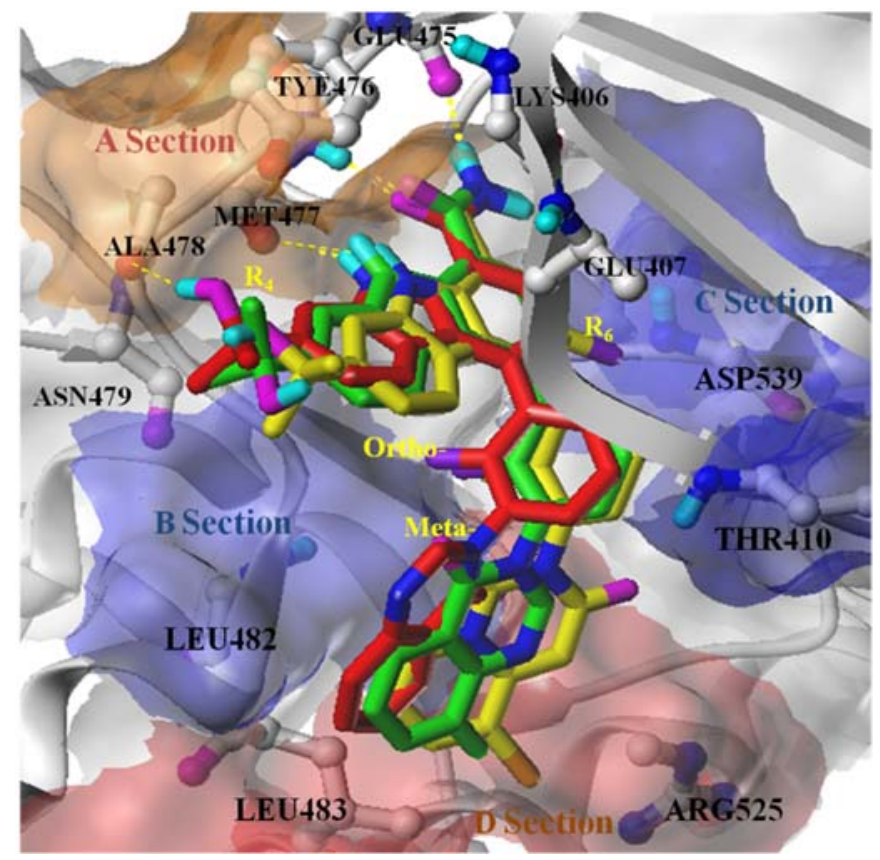

(A)

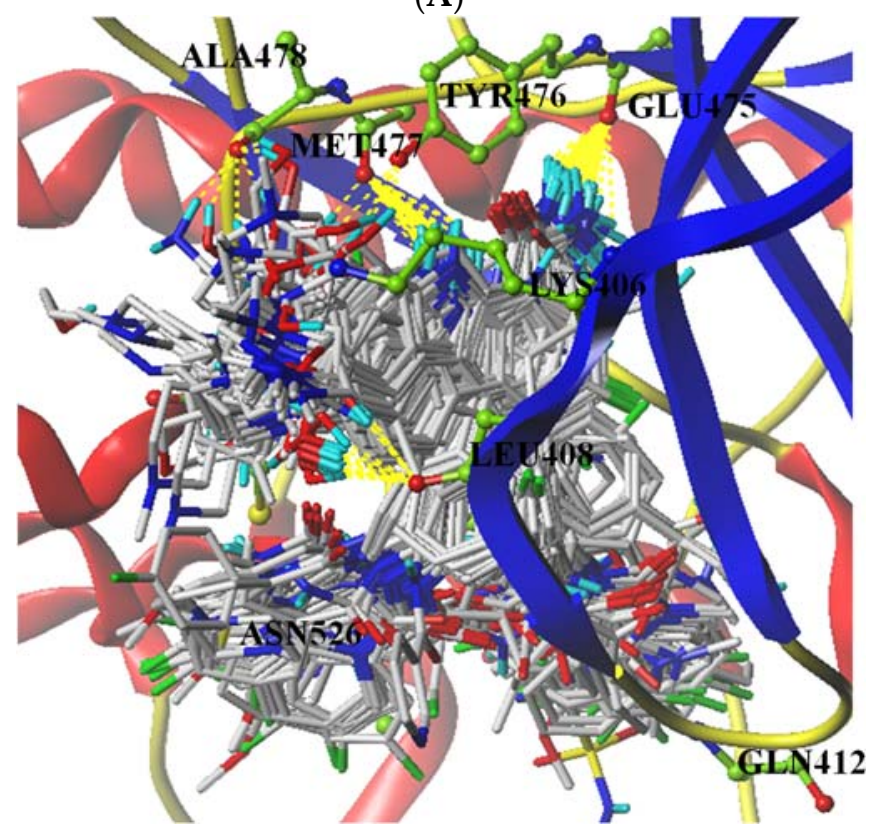

(B)

Figure 2. (A) The binding pose prediction of $\mathbf{7 6}$ (green) compared to ligand (red) found in an X-ray crystal structure; the position of $\mathbf{7 9}$ (yellow) in the active site of the protein and the binding pocket of BTK enzyme. (B) Docking-based alignment of dataset molecules. Hydrogen bonds are represented as yellow dotted lines, and main protein residues are labeled with ball and stick forms. Section A: hinge region; Sections B and C: hydrophobic pocket; Section D: floor loop.

To explain the binding mode, $79\left(\mathrm{IC}_{50}=0.22 \mathrm{nM}\right)$ was selected for more detailed analysis, since it was the most representative inhibitor in the active site of the protein. Based on Figure 2A, the carbazole ring of 79 interacted with $-\mathrm{C}=\mathrm{O}$ and $\mathrm{N}-\mathrm{H}$ of Met 477 and $-\mathrm{C}=\mathrm{O}$ of $\mathrm{Gly} 475$ by hydrogen bonds in 
the hinge region, and interacted with the benzene ring of Tyr 466 by a conjugate effect; among them, Gly475 and Met477 [19] are two significant gatekeeper residues in BTK enzyme. The hydroxyl group at $R_{4}$ also had a hydrogen-bond interaction with Ala478. Chlorine atom at $R_{6}$ formed a hydrophobic interaction with Glu407 and Asp539. The benzene ring's ortho-groups at $\mathrm{R}_{1}$ also interacted with Cys527 and Leu528 through a hydrophobic effect. At the bottom of the pocket, a substituent at the meta-position of the benzene ring was well filled in a floor loop formed by Asn484, Leu483, and Arg525. All these action characteristics proved that $\mathbf{7 9}$ was the most active molecule in the dataset.

As shown in Figure 2B, the selected 132 molecules demonstrate similar features after they are aligned on the common substructure and interact with Gly 475 and Met 477 through hydrogen-bond actions. The activities factors are groups at $R_{4}$ trending toward different directions and groups at $R_{6}$ forming hydrophobic interactions with different residues. Substituents at $R_{1}$ occupied in sites of the floor loop area are also different. These diverse elements resulted in the selected 132 molecules used to perform molecular modeling studies possessing multiple $\mathrm{IC}_{50}$ values.

\section{2. $3 D-Q S A R$ Analysis Studies}

The aligned dataset was subjected to establish 3D-QSAR modeling using partial least squares (PLS) statistics with different field contribution values. In order to select the best field combination model and avoid the over-fitting problem, the stability statistics including cross-validated correlation coefficient $\left(q^{2}\right)$, non-cross-validated correlation coefficient $\left(r^{2}\right)$, a standard error of estimate (SEE), an optimum number of components (NOC), and $F$ statistical values were taken into consideration. As a rule of thumb, $q^{2}$ and $r^{2}$ should have higher values, while SEE should have smaller error values. Therefore, reasonable CoMFA $\left(q^{2}=0.761\right.$, NOC $\left.=6, r^{2}=0.933\right)$ and CoMSIA $\left(q^{2}=0.891\right.$, NOC $=9$, $\left.r^{2}=0.988\right)$ models were developed for the selected training set and the test set. The detailed statistical summary of the CoMFA and CoMSIA analysis are shown in Table 1.

Table 1. Detailed statistical summary of the comparative molecular field analysis (CoMFA) and comparative molecular similarity indices analysis (CoMSIA) models.

\begin{tabular}{|c|c|c|c|c|c|c|c|c|c|c|}
\hline \multirow{2}{*}{ CoMFA } & \multirow{2}{*}{ NOC } & \multirow{2}{*}{$q^{2}$} & \multirow{2}{*}{$r^{2}$} & \multirow{2}{*}{ SEE } & \multirow{2}{*}{$F$ Value } & \multicolumn{5}{|c|}{ Field Contributions } \\
\hline & & & & & & $\mathrm{S}$ & $\mathbf{E}$ & $\mathbf{H}$ & $\mathbf{D}$ & $\mathbf{A}$ \\
\hline $\mathrm{S}+\mathrm{E}$ & 6 & 0.761 & 0.933 & 0.202 & 291.45 & 0.46 & 0.54 & - & - & - \\
\hline \multirow{2}{*}{ CoMSIA } & \multirow{2}{*}{ NOC } & \multirow{2}{*}{$q^{2}$} & \multirow{2}{*}{$r^{2}$} & \multirow{2}{*}{ SEE } & \multirow{2}{*}{$F$ Value } & \multicolumn{5}{|c|}{ Field Contributions } \\
\hline & & & & & & $\mathbf{S}$ & E & $\mathbf{H}$ & $\mathbf{D}$ & $\mathbf{A}$ \\
\hline $\mathrm{S}+\mathrm{E}$ & 5 & 0.851 & 0.941 & 0.188 & 404.01 & 0.198 & 0.802 & - & - & - \\
\hline $\mathrm{S}+\mathrm{E}+\mathrm{H}$ & 7 & 0.862 & 0.972 & 0.132 & 606.51 & 0.110 & 0.554 & 0.336 & - & - \\
\hline$S+E+D$ & 4 & 0.863 & 0.930 & 0.205 & 420.26 & 0.117 & 0.515 & - & 0.367 & - \\
\hline $\mathrm{S}+\mathrm{E}+\mathrm{A}$ & 7 & 0.863 & 0.974 & 0.127 & 657.51 & 0.122 & 0.535 & - & - & 0.342 \\
\hline $\mathrm{S}+\mathrm{E}+\mathrm{H}+\mathrm{D}$ & 9 & 0.875 & 0.985 & 0.095 & 920.97 & 0.069 & 0.424 & 0.235 & 0.272 & - \\
\hline $\mathrm{S}+\mathrm{E}+\mathrm{H}+\mathrm{A}$ & 9 & 0.880 & 0.986 & 0.095 & 923.65 & 0.073 & 0.411 & 0.254 & - & 0.262 \\
\hline $\mathrm{S}+\mathrm{E}+\mathrm{D}+\mathrm{A}$ & 10 & 0.878 & 0.985 & 0.092 & 1031.44 & 0.078 & 0.400 & - & 0.270 & 0.253 \\
\hline $\mathrm{S}+\mathrm{E}+\mathrm{H}+\mathrm{D}+\mathrm{A}$ & 9 & 0.891 & 0.988 & 0.088 & 1076.36 & 0.053 & 0.342 & 0.193 & 0.208 & 0.203 \\
\hline
\end{tabular}

A reasonable CoMFA model was established on the basis of satisfactory statistical values including $\mathrm{q}^{2}, \mathrm{r}^{2}$, and SEE values $(0.761,0.933$, and 0.202 , respectively). When steric, electrostatic, hydrophobic, and $\mathrm{H}$-bond acceptor and donor fields were all employed in the CoMSIA model, $\mathrm{q}^{2}, \mathrm{r}^{2}$, and SEE values also acquired good results $(0.891,0.988$, and 0.088 , respectively), which confirmed that the CoMSIA model was reliable and reasonable. 


\subsection{Contour Map Analysis}

Contour maps for CoMFA and CoMSIA were generated to visualize the information in 3D-QSAR models. The maps of the 3D-QSAR models based on PLS analysis provided a comprehensive understanding of the key structural requirements responsible for the biological activity and are depicted in the following.

\subsubsection{CoMFA Contour Map Analysis}

CoMFA contour maps are vividly displayed in different color areas and illustrate whether the substituted groups are reasonable. Steric contour maps and electrostatic contour maps are shown in Figure 3A,B compared with 79.

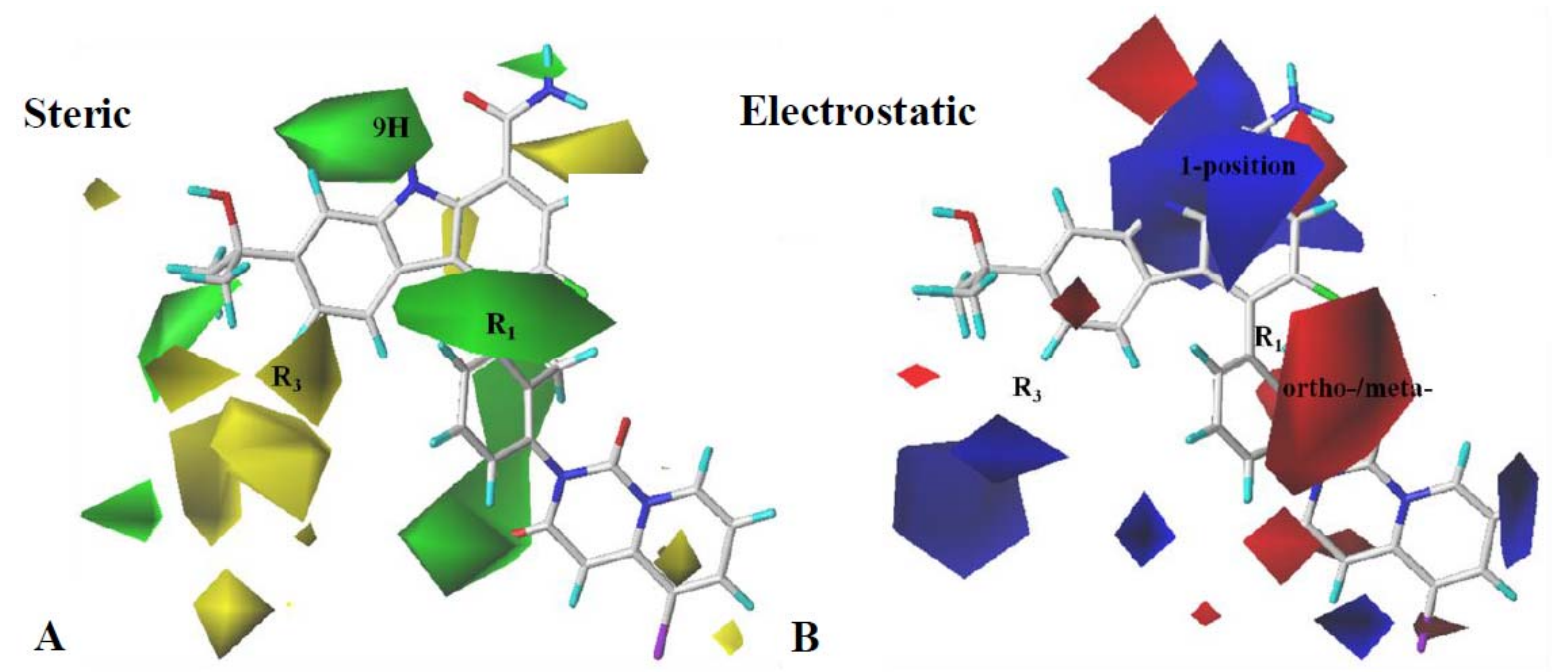

Figure 3. CoMFA StDev*Coeff contour maps. (A) Steric contour map (green: favored; yellow: disfavored). (B) Electrostatic contour map (blue: favored; red: disfavored). Compound $\mathbf{7 9}$ is shown as a capped sticks model.

In the CoMFA steric contour map (Figure 3A), green represents favored bulky groups and yellow represents the opposite. Green contour maps appeared at $9 \mathrm{H}$ of carbazole and $\mathrm{R}_{1}$, indicating that more bulky groups in these regions could improve activity. This possibly explained that inhibitory activity of $53\left(\mathrm{IC}_{50}=18 \mathrm{nM}\right), 54\left(\mathrm{IC}_{50}=18 \mathrm{nM}\right)$, and $55\left(\mathrm{IC}_{50}=17 \mathrm{nM}\right)$ with a methyl at the benzene ring of $\mathrm{R}_{1}$ was twentyfold more potent compared with $127\left(\mathrm{IC}_{50}=390 \mathrm{nM}\right)$ with a hydrogen atom at this position. Besides, a yellow contour at $R_{3}$ suggests that adding a bulky substitution in this region can decrease inhibitory activity, which may explain why the activities of 101-104 ( $\left.\mathrm{IC}_{50}: 110-461 \mathrm{nM}\right)$ with an added morpholinone or piperazinone group at $\mathrm{R}_{3}$ dropped sharply.

In the CoMFA electrostatic contour maps (Figure 3B), blue contours located near 1-position and $\mathrm{R}_{3}$ imply that positive substitutions in these region can increase the activity of the inhibitors. This may explain why $104\left(\mathrm{IC}_{50}=110 \mathrm{nM}\right)$ with a piperazin substituent at $\mathrm{R}_{3}$ was more potent than $102\left(\mathrm{IC}_{50}=308\right.$ $\mathrm{nM}$ ) with morpholin in the same position. Inversely, the red contour in the ortho- and meta-positions of the benzene ring at $\mathrm{R}_{1}$ suggested that negative atoms can increase the activity. This was in accordance with the fact that $84\left(\mathrm{IC}_{50}=032 \mathrm{nM}\right), \mathbf{8 7}\left(\mathrm{IC}_{50}=0.25 \mathrm{nM}\right), \mathbf{1 2 9}\left(\mathrm{IC}_{50}=0.4 \mathrm{nM}\right)$, and $\mathbf{1 3 0}\left(\mathrm{IC}_{50}=0.9 \mathrm{nM}\right)$ possessing nitrogen (negative) atoms at $\mathrm{R}_{1}$ demonstrated high BTK inhibition activity.

\subsubsection{CoMSIA Contour Map Analysis}

CoMSIA StDev*Coeff contour map analysis of steric, electrostatic, hydrophobic, and H-bond donor and H-bond acceptor fields are revealed in the following images, with $\mathbf{7 9}$ as the template molecule in the active site of BTK. 
In the CoMSIA steric contour map (Figure 4A), the carbazole ring of $\mathbf{7 9}$, sheathed by a giant green block, indicates that the bulky groups here can increase the activity. Yellow contours near the extensional area of $R_{3}$ suggest the unfavorable influence of bulky groups. In Figure $4 B$, the electron-donating group and electron-withdrawing group covered by blue and red contours were represented at 1-position and ortho-position of the benzene ring at $\mathrm{R}_{1}$, respectively. Compared to the steric/electrostatic contour maps of CoMFA and CoMSIA, they are very similar, except that the largest green field also involved an outstretched space in the carbazole scaffold, which means that adding bulky groups to this region improved activity.

The hydrophobic contour map from CoMSIA is shown in Figure 5. Orange contours near the benzene ring of $R_{1}$ and the hydrocarbyl of $R_{4}$, as well as the extension space of $R_{3}$, indicate that the hydrophobic groups in those areas are beneficial for inhibitory activities. This is consistent with the fact that 95-100 ( $\left.\mathrm{IC}_{50}: 0.35-2.0 \mathrm{nM}\right)$, possessing halogen and hydrocarbyl substituents in these areas, have more potent activities than $54\left(\mathrm{IC}_{50}=18 \mathrm{nM}\right)$ and $55\left(\mathrm{IC}_{50}=17 \mathrm{nM}\right)$ with the hydroxyl and amino groups. White contours around $\mathrm{R}_{1}$ reveal that the hydrophobic groups here do not help to enhance the activity. Hence, $121\left(\mathrm{IC}_{50}=16 \mathrm{nM}\right), \mathbf{1 2 2}\left(\mathrm{IC}_{50}=15 \mathrm{nM}\right), \mathbf{1 2 4}\left(\mathrm{IC}_{50}=17 \mathrm{nM}\right)$, and $\mathbf{1 2 5}\left(\mathrm{IC}_{50}=16 \mathrm{nM}\right)$, possessing aromatic halogen substitutions at this position, held lower activity levels than 129-132 $\left(\mathrm{IC}_{50}: 0.4-1.0 \mathrm{nM}\right)$.

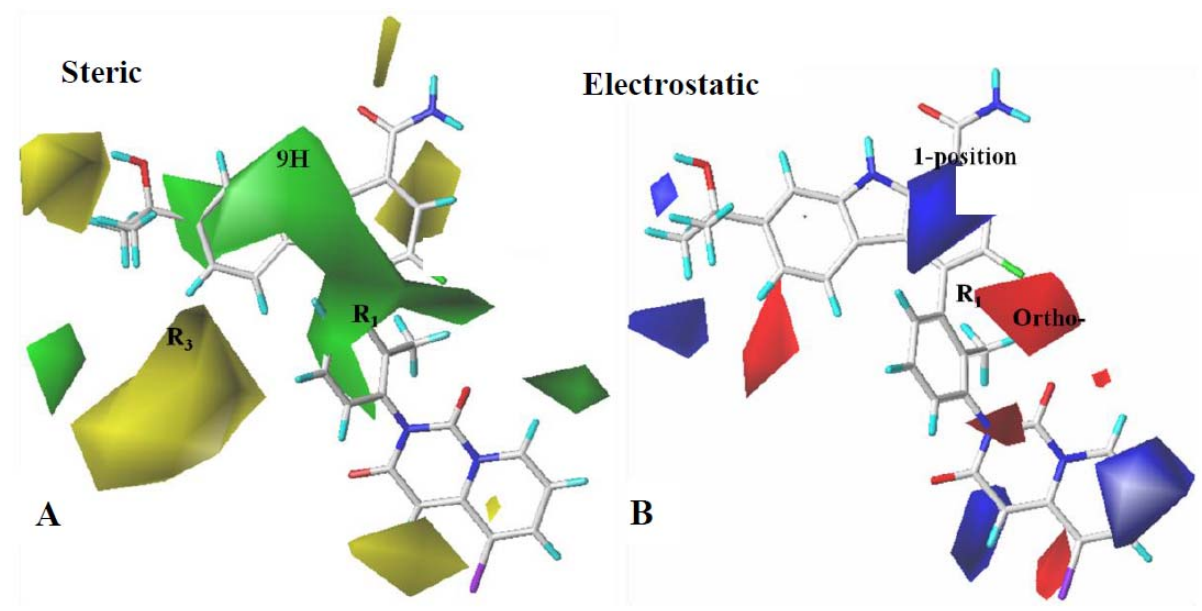

Figure 4. CoMSIA StDev*Coeff contour maps. (A) Steric contour map (green: favored; yellow: disfavored). (B) Electrostatic contour map (blue: favored; red: disfavored). Compound 79 is shown as a capped sticks model.

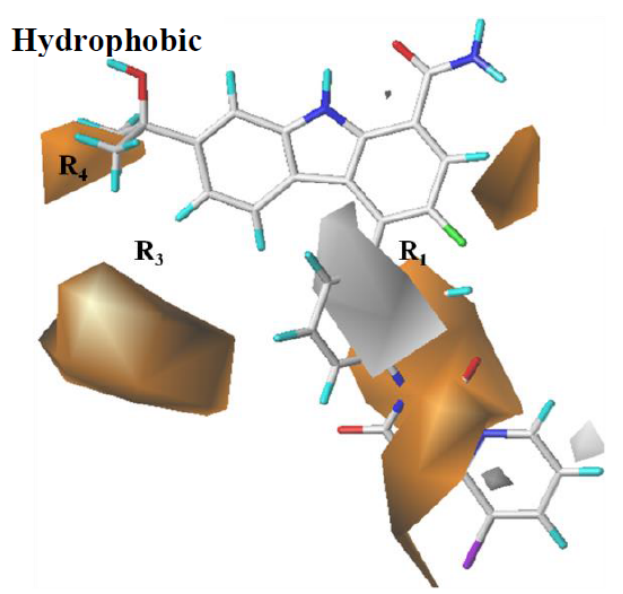

Figure 5. CoMSIA StDev*Coeff contour maps: Hydrophobic contour map (orange: favored; white: disfavored). Compound $\mathbf{7 9}$ is shown as a capped sticks model. 
The H-bond donor and acceptor of the CoMSIA contour map are shown in Figure 6A,B, respectively. The remarkable cyan contour on the top of the carbazole ring implies that the presence of hydrogen-bond donor groups might enhance bioactivity. This could be validated if it is found that 1-132 possess hydrogen atoms as hydrogen-bond donor groups in the same positions. The magenta contours around 1-position and meta-position of the benzene ring at $\mathrm{R}_{1}$ show that $\mathrm{H}$-bond acceptor groups in these places can increase the activity of inhibitors. This might explain why $74\left(\mathrm{IC}_{50}=0.79 \mathrm{nM}\right)$ and $75\left(\mathrm{IC}_{50}=1.2 \mathrm{nM}\right)$ with two carbonyl substituents at $\mathrm{R}_{1}$ displayed better $\mathrm{IC}_{50}$ values than 1 $\left(\mathrm{IC}_{50}=44 \mathrm{nM}\right)$.

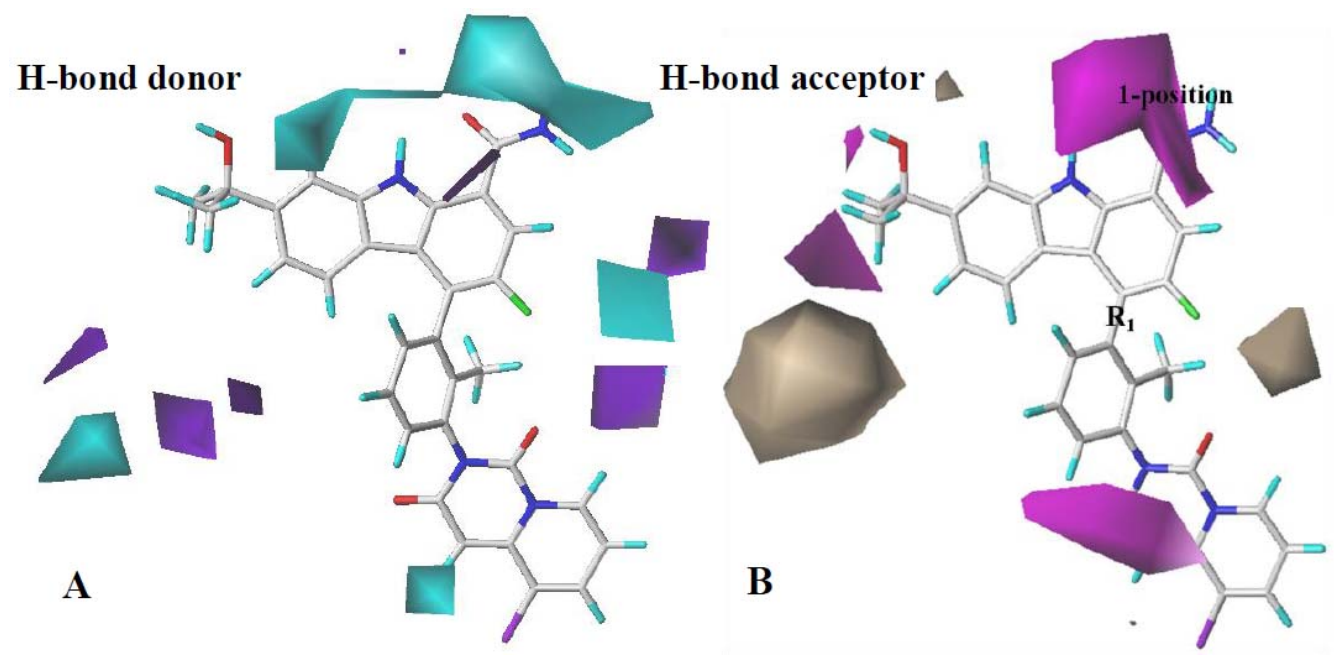

Figure 6. CoMSIA StDev*Coeff contour maps. (A) H-bond donor map (cyan: favored; purple: disfavored). (B) H-bond acceptor map (magenta: favored; brown: disfavored). Compound 79 is shown as a capped sticks model.

\subsection{Model Validation of CoMFA and CoMSIA Models}

The experimental and predicted activity values of CoMFA and CoMSIA models are depicted in Table 2, and their scatter plots are shown in Figure 7.

Table 2. The experimental and predicted activity values for the developed models.

\begin{tabular}{cccccc}
\hline \multirow{2}{*}{ Training Set Compounds } & \multirow{2}{*}{ pIC $_{\mathbf{5 0}}$} & \multicolumn{2}{c}{ CoMFA } & \multicolumn{2}{c}{ CoMSIA } \\
\cline { 3 - 6 } & & Predicted & Residuals & Predicted & Residuals \\
\hline $\mathbf{1}$ & 4.3565 & 4.304 & 0.0525 & 4.286 & 0.0705 \\
$\mathbf{3}$ & 5.6778 & 5.554 & 0.1239 & 5.730 & -0.0526 \\
$\mathbf{4}$ & 5.8239 & 5.526 & 0.2981 & 5.790 & 0.0344 \\
$\mathbf{5}$ & 5.6576 & 5.649 & 0.0082 & 5.673 & -0.0157 \\
$\mathbf{6}$ & 5.7447 & 5.758 & -0.0135 & 5.753 & -0.008 \\
$\mathbf{7}$ & 5.6576 & 5.524 & 0.1337 & 5.697 & -0.0393 \\
$\mathbf{8}$ & 5.6576 & 5.751 & -0.0938 & 5.659 & -0.0011 \\
$\mathbf{9}$ & 5.6576 & 5.735 & -0.0776 & 5.656 & 0.0015 \\
$\mathbf{1 0}$ & 5.6383 & 5.493 & 0.1456 & 5.640 & -0.0015 \\
$\mathbf{1 1}$ & 5.7959 & 6.058 & -0.2625 & 5.957 & -0.1615 \\
$\mathbf{1 2}$ & 6.0969 & 6.060 & 0.0366 & 6.102 & -0.0048 \\
$\mathbf{1 3}$ & 5.6990 & 5.631 & 0.0675 & 5.653 & 0.0459 \\
$\mathbf{1 4}$ & 6.0000 & 6.042 & -0.0422 & 5.925 & 0.0755 \\
$\mathbf{1 5}$ & 6.1551 & 6.234 & -0.0789 & 6.087 & 0.0681 \\
$\mathbf{1 7}$ & 5.8861 & 5.641 & 0.2452 & 5.885 & 0.0008 \\
$\mathbf{1 8}$ & 5.6990 & 5.583 & 0.1156 & 5.704 & -0.0049 \\
$\mathbf{1 9}$ & 5.7447 & 5.821 & -0.0766 & 5.761 & -0.0162 \\
$\mathbf{2 0}$ & 5.5376 & 5.698 & -0.16 & 5.638 & -0.1001 \\
$\mathbf{2 2}$ & 5.8539 & 5.615 & 0.2385 & 5.855 & -0.0012 \\
$\mathbf{2 3}$ & 5.7213 & 5.465 & 0.2565 & 5.751 & -0.0294 \\
\hline
\end{tabular}


Table 2. Cont.

\begin{tabular}{|c|c|c|c|c|c|}
\hline \multirow{2}{*}{ Training Set Compounds } & \multirow{2}{*}{$\mathrm{pIC}_{50}$} & \multicolumn{2}{|c|}{ CoMFA } & \multicolumn{2}{|c|}{ CoMSIA } \\
\hline & & Predicted & Residuals & Predicted & Residuals \\
\hline 24 & 5.7959 & 5.917 & -0.1211 & 5.731 & 0.0644 \\
\hline 25 & 5.5229 & 5.901 & -0.3785 & 5.516 & 0.0073 \\
\hline 26 & 5.7213 & 5.876 & -0.1547 & 5.908 & -0.1865 \\
\hline 28 & 6.0924 & 6.208 & -0.1156 & 6.099 & 0.0066 \\
\hline 29 & 6.2076 & 6.337 & -0.1291 & 6.36 & -0.1519 \\
\hline 31 & 5.5528 & 5.597 & -0.0445 & 5.654 & -0.1009 \\
\hline 32 & 5.0458 & 5.081 & -0.0354 & 5.010 & 0.0357 \\
\hline 33 & 5.5850 & 5.744 & -0.1586 & 5.518 & 0.0669 \\
\hline 34 & 5.8239 & 6.272 & -0.4485 & 6.017 & -0.1929 \\
\hline 36 & 5.7695 & 5.951 & -0.1814 & 5.642 & 0.1275 \\
\hline 37 & 6.2007 & 6.017 & 0.1837 & 6.080 & 0.1203 \\
\hline 38 & 6.2840 & 6.026 & 0.2581 & 6.119 & 0.165 \\
\hline 39 & 6.0269 & 5.864 & 0.1626 & 6.068 & -0.0413 \\
\hline 40 & 6.0000 & 6.121 & -0.1213 & 5.939 & 0.0609 \\
\hline 42 & 5.7695 & 5.786 & -0.0166 & 5.831 & -0.0613 \\
\hline 43 & 5.7959 & 5.791 & 0.0051 & 5.737 & 0.059 \\
\hline 44 & 5.7959 & 5.513 & 0.2828 & 5.760 & 0.0358 \\
\hline 45 & 6.0315 & 6.176 & -0.1442 & 6.172 & -0.1406 \\
\hline 46 & 5.6383 & 6.035 & -0.397 & 5.728 & -0.0898 \\
\hline 47 & 5.8239 & 5.844 & -0.02 & 5.909 & -0.0852 \\
\hline 48 & 5.5850 & 5.787 & -0.2015 & 5.695 & -0.1097 \\
\hline 49 & 5.3010 & 5.244 & 0.0572 & 5.325 & -0.0241 \\
\hline 50 & 5.3010 & 5.393 & -0.0917 & 5.275 & 0.026 \\
\hline 52 & 4.7959 & 5.112 & -0.3163 & 4.728 & 0.0682 \\
\hline 54 & 4.7447 & 4.654 & 0.0905 & 4.849 & -0.1045 \\
\hline 55 & 4.7695 & 4.684 & 0.0851 & 4.826 & -0.0568 \\
\hline 56 & 4.8239 & 4.779 & 0.045 & 4.703 & 0.1207 \\
\hline 57 & 4.7959 & 4.792 & 0.0037 & 4.902 & -0.1061 \\
\hline 59 & 4.7695 & 4.634 & 0.1357 & 4.657 & 0.1121 \\
\hline 60 & 5.6990 & 5.694 & 0.0045 & 5.628 & 0.0712 \\
\hline 61 & 5.6990 & 5.440 & 0.2595 & 5.636 & 0.0632 \\
\hline 62 & 4.7959 & 4.760 & 0.0359 & 4.871 & -0.0747 \\
\hline 63 & 4.7695 & 4.812 & -0.0421 & 4.753 & 0.0165 \\
\hline 64 & 5.3010 & 5.582 & -0.2807 & 5.326 & -0.0249 \\
\hline 65 & 4.8239 & 4.686 & 0.1384 & 4.849 & -0.0248 \\
\hline 66 & 5.7213 & 5.880 & -0.159 & 5.762 & -0.0407 \\
\hline 67 & 5.6990 & 5.454 & 0.2446 & 5.714 & -0.0154 \\
\hline 68 & 5.6778 & 5.651 & 0.0267 & 5.790 & -0.1123 \\
\hline 69 & 5.8539 & 5.991 & -0.1368 & 5.792 & 0.0624 \\
\hline 70 & 5.7695 & 5.587 & 0.183 & 5.727 & 0.0424 \\
\hline 71 & 5.7959 & 5.955 & -0.1589 & 5.760 & 0.0362 \\
\hline 72 & 6.1805 & 6.234 & -0.0532 & 6.087 & 0.0931 \\
\hline 73 & 6.3872 & 6.487 & -0.1002 & 6.355 & 0.0321 \\
\hline 76 & 5.3979 & 5.391 & 0.007 & 5.528 & -0.1299 \\
\hline 77 & 6.3468 & 6.220 & 0.1271 & 6.272 & 0.0749 \\
\hline 79 & 6.6576 & 6.305 & 0.3527 & 6.596 & 0.0612 \\
\hline 80 & 6.1135 & 6.136 & -0.0222 & 6.213 & -0.0992 \\
\hline 81 & 6.3188 & 6.131 & 0.188 & 6.402 & -0.0837 \\
\hline 83 & 6.2291 & 6.107 & 0.1225 & 6.339 & -0.1095 \\
\hline 85 & 6.0000 & 6.025 & -0.0254 & 6.029 & -0.0285 \\
\hline 86 & 6.3098 & 6.404 & -0.0941 & 6.365 & -0.0557 \\
\hline 89 & 5.8861 & 6.291 & -0.4053 & 6.112 & -0.2261 \\
\hline 90 & 6.0915 & 6.111 & -0.0196 & 6.131 & -0.0396 \\
\hline 92 & 6.3566 & 6.171 & 0.186 & 6.281 & 0.0751 \\
\hline 93 & 6.2602 & 6.274 & -0.0138 & 6.251 & -0.0092 \\
\hline 94 & 6.0706 & 6.208 & -0.1374 & 6.099 & -0.0288 \\
\hline 95 & 6.0410 & 5.983 & 0.0577 & 5.981 & 0.0595 \\
\hline 96 & 6.0000 & 5.468 & 0.5325 & 5.981 & 0.0187 \\
\hline 97 & 6.0458 & 6.086 & -0.0406 & 6.038 & 0.0077 \\
\hline
\end{tabular}


Table 2. Cont.

\begin{tabular}{|c|c|c|c|c|c|}
\hline \multirow{2}{*}{ Training Set Compounds } & \multirow{2}{*}{$\mathrm{pIC}_{50}$} & \multicolumn{2}{|c|}{ CoMFA } & \multicolumn{2}{|c|}{ CoMSIA } \\
\hline & & Predicted & Residuals & Predicted & Residuals \\
\hline 98 & 5.6990 & 5.934 & -0.2348 & 5.638 & 0.0608 \\
\hline 99 & 6.3468 & 6.242 & 0.1046 & 6.366 & -0.0187 \\
\hline 100 & 6.4559 & 6.074 & 0.3816 & 6.496 & -0.0397 \\
\hline 105 & 4.5528 & 4.125 & 0.4278 & 4.538 & 0.015 \\
\hline 108 & 4.8239 & 4.736 & 0.0878 & 4.826 & -0.0023 \\
\hline 109 & 4.4949 & 4.403 & 0.0923 & 4.379 & 0.1156 \\
\hline 110 & 4.6198 & 4.870 & -0.2505 & 4.523 & 0.0971 \\
\hline 111 & 4.1487 & 3.873 & 0.2756 & 4.082 & 0.0663 \\
\hline 112 & 4.2291 & 4.703 & -0.4742 & 4.182 & 0.0468 \\
\hline 113 & 3.9872 & 4.031 & -0.0437 & 3.984 & 0.0036 \\
\hline 117 & 4.7212 & 4.481 & 0.2403 & 4.758 & -0.0366 \\
\hline 119 & 4.7959 & 4.747 & 0.0485 & 4.809 & -0.0131 \\
\hline 121 & 4.7959 & 4.881 & -0.0849 & 4.889 & -0.0936 \\
\hline 122 & 4.8239 & 4.695 & 0.1286 & 4.871 & -0.0473 \\
\hline 123 & 4.7959 & 4.888 & -0.0918 & 4.820 & -0.0243 \\
\hline 124 & 4.7695 & 5.019 & -0.2491 & 4.821 & -0.0511 \\
\hline 125 & 4.7959 & 5.032 & -0.2358 & 4.751 & 0.0454 \\
\hline 129 & 6.3979 & 6.202 & 0.1955 & 6.281 & 0.1174 \\
\hline 130 & 6.0458 & 6.086 & -0.0406 & 6.038 & 0.0077 \\
\hline 131 & 6.0000 & 5.468 & 0.5325 & 5.981 & 0.0187 \\
\hline 132 & 6.5850 & 6.559 & 0.0255 & 6.608 & -0.0229 \\
\hline \multirow{2}{*}{ Test Set Compounds } & \multirow{2}{*}{$\mathrm{pIC}_{50}$} & \multicolumn{2}{|c|}{ CoMFA } & \multicolumn{2}{|c|}{ CoMSIA } \\
\hline & & Predicted & Residuals & Predicted & Residuals \\
\hline $2 *$ & 5.3010 & 5.505 & -0.2035 & 5.296 & 0.0055 \\
\hline $16 *$ & 5.8861 & 5.526 & 0.3598 & 5.871 & 0.0147 \\
\hline 21 * & 5.4948 & 5.751 & -0.2562 & 5.648 & -0.1528 \\
\hline $27^{*}$ & 5.7213 & 5.631 & 0.0898 & 5.618 & 0.1034 \\
\hline $30 *$ & 5.585 & 5.522 & 0.0629 & 5.554 & 0.0312 \\
\hline $35 *$ & 5.6383 & 6.035 & -0.397 & 5.728 & -0.0898 \\
\hline $41 *$ & 5.6778 & 5.696 & -0.0185 & 5.738 & -0.0601 \\
\hline $51 *$ & 5.6990 & 5.581 & 0.1182 & 5.596 & 0.103 \\
\hline $53 *$ & 4.7447 & 4.732 & 0.0132 & 4.745 & -0.0001 \\
\hline $58 *$ & 5.5229 & 5.515 & 0.0076 & 5.364 & 0.1585 \\
\hline $74 *$ & 6.1024 & 6.085 & 0.0172 & 6.059 & 0.043 \\
\hline $75^{*}$ & 5.9208 & 5.971 & -0.0502 & 5.797 & 0.124 \\
\hline $78 *$ & 6.3372 & 6.220 & 0.1176 & 6.272 & 0.0654 \\
\hline $82 *$ & 6.4559 & 6.312 & 0.1437 & 6.417 & 0.0393 \\
\hline $84 *$ & 6.4948 & 6.451 & 0.0443 & 6.432 & 0.0631 \\
\hline $87^{*}$ & 6.6021 & 6.472 & 0.1298 & 6.523 & 0.079 \\
\hline $88 *$ & 6.0000 & 6.316 & -0.3157 & 6.074 & -0.0739 \\
\hline $91 *$ & 6.2076 & 6.337 & -0.1291 & 6.360 & -0.1519 \\
\hline $101 *$ & 3.7235 & 3.525 & 0.1989 & 3.684 & 0.0392 \\
\hline $102 *$ & 3.5114 & 3.734 & -0.2221 & 3.580 & -0.0684 \\
\hline $103 *$ & 3.3363 & 3.648 & -0.3118 & 3.523 & -0.1868 \\
\hline $104^{*}$ & 3.9586 & 3.937 & 0.0218 & 3.940 & 0.0186 \\
\hline $106 *$ & 4.0555 & 3.886 & 0.1694 & 4.104 & -0.048 \\
\hline $107^{*}$ & 3.4214 & 3.776 & -0.3549 & 3.506 & -0.0851 \\
\hline $114^{*}$ & 4.3565 & 4.110 & 0.2468 & 4.286 & 0.0708 \\
\hline $115^{*}$ & 3.8962 & 3.795 & 0.1014 & 3.799 & 0.0972 \\
\hline $116 *$ & 3.9957 & 4.494 & -0.4982 & 4.254 & -0.2585 \\
\hline $118^{*}$ & 4.6576 & 4.579 & 0.0789 & 4.488 & 0.1701 \\
\hline $120 *$ & 4.9208 & 4.915 & 0.0063 & 4.831 & 0.0897 \\
\hline $126 *$ & 4.7959 & 4.816 & -0.0204 & 4.685 & 0.1113 \\
\hline $127^{*}$ & 3.4089 & 3.904 & -0.4953 & 3.483 & -0.0741 \\
\hline $128 *$ & 4.8239 & 4.873 & -0.0489 & 4.758 & 0.0663 \\
\hline
\end{tabular}

* Test set. 


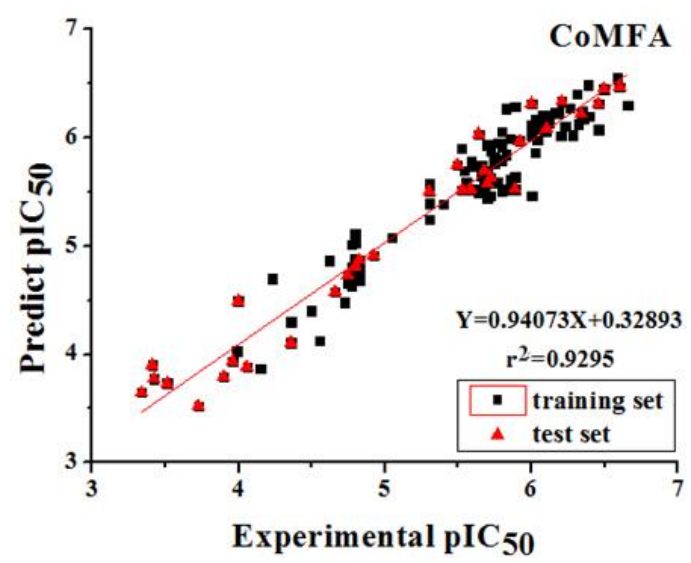

(A)

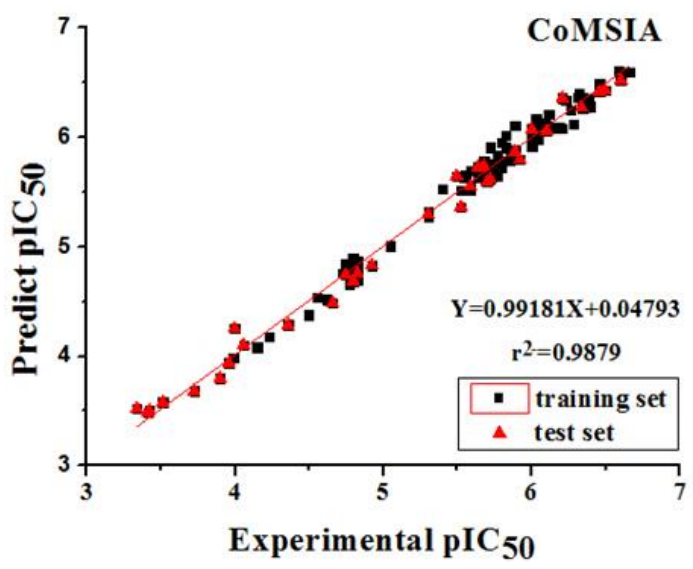

(B)

Figure 7. Correlation between the predicted and experimental activities of the training and test set compounds. (A) The scatter plot of CoMFA. (B) The scatter plot of CoMSIA. Black squares represent the training set; red triangles represent the test set.

Based on the above data, the correlation coefficient between the predicted and experimental activities generated by the CoMFA models were 0.94073 and its analytical error was 0.32893 , which confirmed that the established CoMFA models are reliable and reasonable. Similarly, the correlation coefficient and analytical error of the CoMSIA model were 0.99181 and 0.04793 , respectively, and these two values verify that the CoMSIA models are accurate and reliable. Both CoMFA and CoMSIA models can be further used to predict activities of newly designed inhibitors.

\section{Materials and Methods}

\subsection{Collection of the Dataset}

A series of carbazole-carboxamide-based BTK inhibitors (BMS-986142 analogues) were used for the study. The 132 selected molecules [14,20-23] had a basic tricyclic skeleton and a similar binding mode with the BTK enzyme, which could be well superimposed in the alignment module. These BMS-986142 analogues were evenly distributed in an inhibitory activity range from 0.1 to 1000 $\mathrm{nM}$. These compounds were optimized by energy minimization with a tripos force field in Sybyl-X 2.0 [24] and generated three-dimensional conformations after docking into the BTK-enzyme-binding site. The biological data expressed as $\mathrm{IC}_{50}$ values were converted into $\mathrm{pIC}_{50}\left(-\log \mathrm{IC}_{50}\right)$ values, which were used as dependent variables in the following QSAR analyses [25]. The selected 132 BTK inhibitors were divided into a test set consisting of 32 molecules for model validation and a training set including 100 compounds for model generation. Thirty-two compounds in the test set were selected randomly and included compounds with a uniformly distributed range of $\mathrm{pIC}_{50}$ values from 3.336 to 6.658 , covering more than $3 \log$ units, which is fit for 3D QSAR studies [26]. The conformation of the most active compound, 79, was selected as a template structure to sketch the rest of the molecules [27]. The complete dataset (1-132) taken for study is shown in Table 3. 
Table 3. Chemical structures of $\mathbf{1 - 1 3 2}$ with their $\mathrm{pIC}_{50}$.

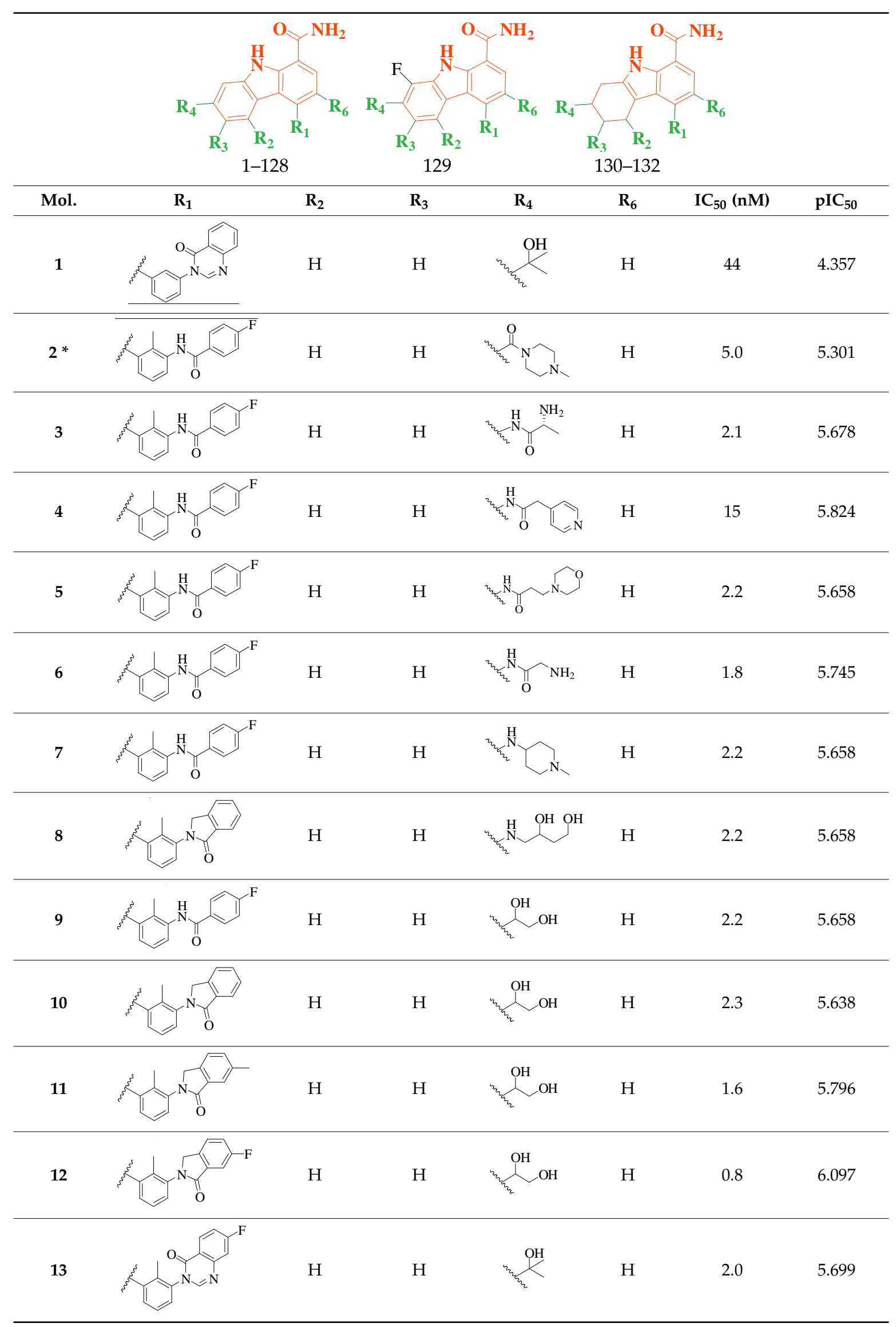


Table 3. Cont.

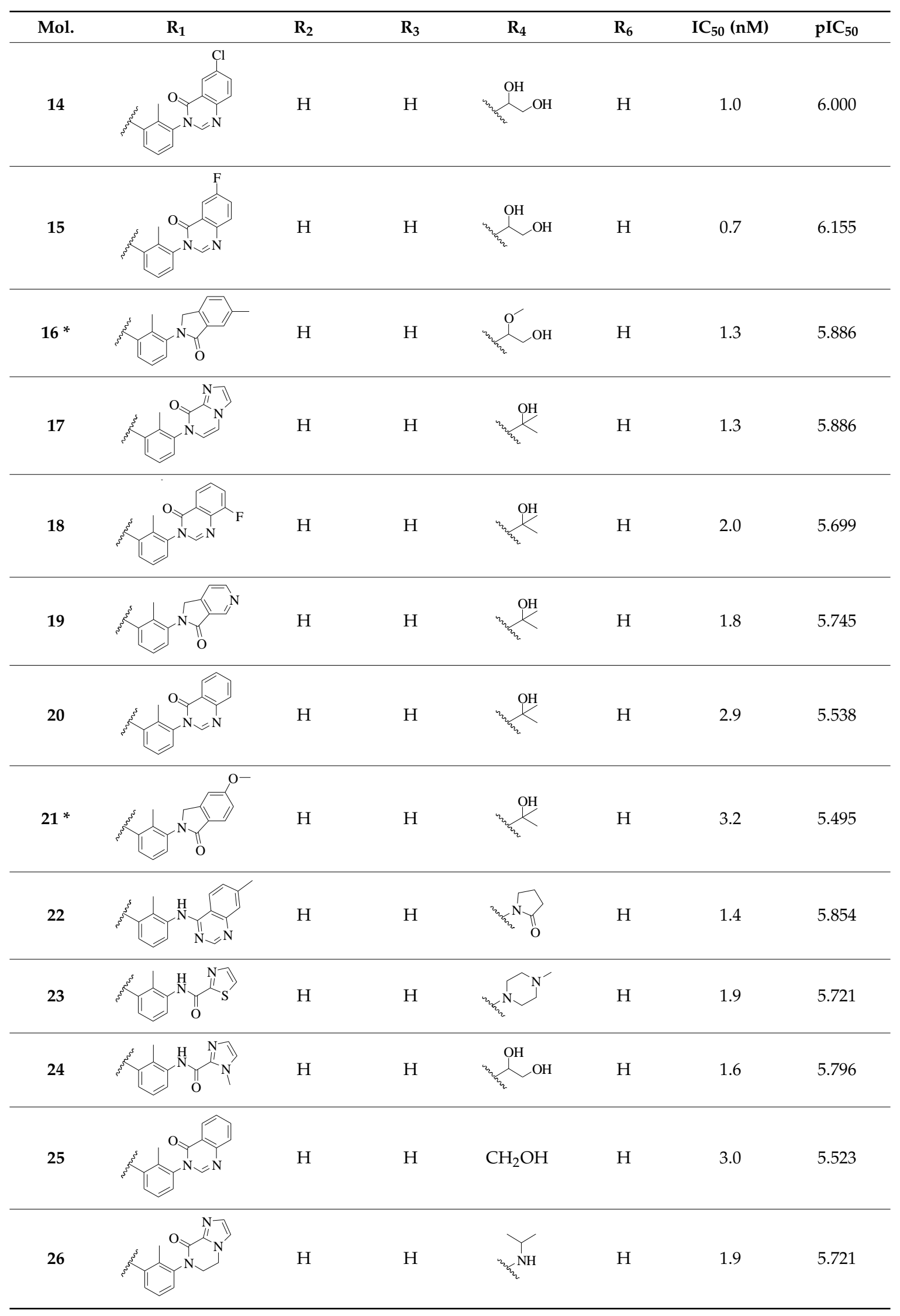


Table 3. Cont.

\begin{tabular}{|c|c|c|c|c|c|c|c|}
\hline Mol. & $\mathbf{R}_{1}$ & $\mathbf{R}_{2}$ & $\mathbf{R}_{3}$ & $\mathbf{R}_{4}$ & $\mathbf{R}_{6}$ & $\mathrm{IC}_{50}(\mathrm{nM})$ & $\mathrm{pIC}_{50}$ \\
\hline 27 * & & $\mathrm{H}$ & $\mathrm{H}$ & & $\mathrm{H}$ & 1.9 & 5.721 \\
\hline 28 & & $\mathrm{H}$ & $\mathrm{H}$ & & $\mathrm{H}$ & 0.81 & 6.092 \\
\hline 29 & & $\mathrm{H}$ & $\mathrm{H}$ & & $\mathrm{H}$ & 0.62 & 6.208 \\
\hline $30 *$ & & $\mathrm{H}$ & $\mathrm{H}$ & & $\mathrm{H}$ & 2.6 & 5.585 \\
\hline 31 & & $\mathrm{H}$ & $\mathrm{H}$ & & $\mathrm{H}$ & 2.8 & 5.553 \\
\hline 32 & & $\mathrm{H}$ & $\mathrm{H}$ & & $\mathrm{H}$ & 9.0 & 5.046 \\
\hline 33 & & $\mathrm{H}$ & $\mathrm{H}$ & & $\mathrm{H}$ & 2.6 & 5.585 \\
\hline 34 & & $\mathrm{H}$ & $\mathrm{H}$ & & $\mathrm{H}$ & 1.5 & 5.824 \\
\hline $35 *$ & & $\mathrm{H}$ & $\mathrm{H}$ & & $\mathrm{H}$ & 2.3 & 5.638 \\
\hline 36 & & $\mathrm{H}$ & $\mathrm{H}$ & & $\mathrm{H}$ & 1.7 & 5.770 \\
\hline 37 & & $\mathrm{H}$ & $\mathrm{H}$ & & $\mathrm{H}$ & 0.63 & 6.201 \\
\hline 38 & & $\mathrm{H}$ & $\mathrm{H}$ & & $\mathrm{H}$ & 0.52 & 6.284 \\
\hline 39 & & $\mathrm{H}$ & $\mathrm{H}$ & & $\mathrm{H}$ & 0.94 & 6.027 \\
\hline
\end{tabular}


Table 3. Cont.

\begin{tabular}{|c|c|c|c|c|c|c|c|}
\hline Mol. & $\mathbf{R}_{1}$ & $\mathbf{R}_{\mathbf{2}}$ & $\mathbf{R}_{3}$ & $\mathbf{R}_{4}$ & $\mathbf{R}_{6}$ & $\mathrm{IC}_{50}(\mathrm{nM})$ & $\mathrm{pIC}_{50}$ \\
\hline 40 & & $\mathrm{H}$ & $\mathrm{H}$ & & $\mathrm{H}$ & 1.0 & 6.000 \\
\hline $41 *$ & & $\mathrm{H}$ & $\mathrm{H}$ & & $\mathrm{H}$ & 2.1 & 5.678 \\
\hline 42 & & $\mathrm{H}$ & $\mathrm{H}$ & & $\mathrm{H}$ & 1.7 & 5.770 \\
\hline 43 & & $\mathrm{H}$ & $\mathrm{H}$ & & $\mathrm{H}$ & 1.6 & 5.796 \\
\hline 44 & & $\mathrm{H}$ & $\mathrm{H}$ & & $\mathrm{H}$ & 1.6 & 5.796 \\
\hline 45 & & $\mathrm{H}$ & $\mathrm{H}$ & & $\mathrm{H}$ & 0.93 & 6.032 \\
\hline 46 & & $\mathrm{H}$ & $\mathrm{H}$ & & $\mathrm{H}$ & 2.3 & 5.638 \\
\hline 47 & & $\mathrm{H}$ & $\mathrm{H}$ & & $\mathrm{H}$ & 1.5 & 5.824 \\
\hline 48 & & $\mathrm{H}$ & $\mathrm{H}$ & & $\mathrm{H}$ & 2.6 & 5.585 \\
\hline 49 & & $\mathrm{H}$ & $\mathrm{H}$ & & $\mathrm{H}$ & 5.0 & 5.301 \\
\hline 50 & & $\mathrm{H}$ & $\mathrm{H}$ & & $\mathrm{H}$ & 5.0 & 5.301 \\
\hline $51 *$ & & $\mathrm{H}$ & $\mathrm{H}$ & & $\mathrm{H}$ & 2.0 & 5.699 \\
\hline 52 & & $\mathrm{H}$ & $\mathrm{H}$ & & $\mathrm{H}$ & 16 & 4.796 \\
\hline
\end{tabular}


Table 3. Cont.

\begin{tabular}{|c|c|c|c|c|c|c|c|}
\hline Mol. & $\mathbf{R}_{1}$ & $\mathbf{R}_{2}$ & $\mathbf{R}_{3}$ & $\mathbf{R}_{\mathbf{4}}$ & $\mathbf{R}_{6}$ & $\mathrm{IC}_{50}(\mathrm{nM})$ & $\mathrm{pIC}_{50}$ \\
\hline $53 *$ & & $\mathrm{H}$ & $\mathrm{H}$ & & $\mathrm{H}$ & 18 & 4.745 \\
\hline 54 & & $\mathrm{H}$ & $\mathrm{H}$ & & $\mathrm{H}$ & 18 & 4.745 \\
\hline 55 & & $\mathrm{H}$ & $\mathrm{H}$ & & $\mathrm{H}$ & 17 & 4.770 \\
\hline 56 & & $\mathrm{H}$ & $\mathrm{H}$ & & $\mathrm{H}$ & 15 & 4.824 \\
\hline 57 & & $\mathrm{H}$ & $\mathrm{H}$ & & $\mathrm{H}$ & 16 & 4.796 \\
\hline $58 *$ & & $\mathrm{H}$ & $\mathrm{H}$ & & $\mathrm{H}$ & 3.0 & 5.523 \\
\hline 59 & & $\mathrm{H}$ & $\mathrm{H}$ & & $\mathrm{H}$ & 17 & 4.770 \\
\hline 60 & & $\mathrm{H}$ & $\mathrm{H}$ & & $\mathrm{H}$ & 2.0 & 5.699 \\
\hline 61 & & $\mathrm{H}$ & $\mathrm{H}$ & & $\mathrm{H}$ & 18 & 5.699 \\
\hline 62 & & $\mathrm{H}$ & $\mathrm{H}$ & & $\mathrm{H}$ & 16 & 4.796 \\
\hline 63 & & $\mathrm{H}$ & $\mathrm{H}$ & & $\mathrm{H}$ & 17 & 4.770 \\
\hline 64 & & $\mathrm{H}$ & $\mathrm{H}$ & & $\mathrm{H}$ & 5.0 & 5.301 \\
\hline 65 & & $\mathrm{H}$ & $\mathrm{H}$ & & $\mathrm{H}$ & 15 & 4.824 \\
\hline 66 & & $\mathrm{H}$ & $\mathrm{H}$ & $\mathrm{N}$ & $\mathrm{H}$ & 1.9 & 5.721 \\
\hline
\end{tabular}


Table 3. Cont.

\begin{tabular}{|c|c|c|c|c|c|c|c|}
\hline Mol. & $\mathbf{R}_{1}$ & $\mathbf{R}_{2}$ & $\mathbf{R}_{3}$ & $\mathbf{R}_{4}$ & $\mathbf{R}_{6}$ & $\mathrm{IC}_{50}(\mathrm{nM})$ & $\mathrm{pIC}_{50}$ \\
\hline 67 & & $\mathrm{H}$ & $\mathrm{H}$ & & $\mathrm{H}$ & 2.0 & 5.699 \\
\hline 68 & & $\mathrm{H}$ & $\mathrm{H}$ & & $\mathrm{H}$ & 2.1 & 5.678 \\
\hline 69 & & $\mathrm{H}$ & $\mathrm{H}$ & & $\mathrm{H}$ & 1.4 & 5.854 \\
\hline 70 & & $\mathrm{H}$ & $\mathrm{H}$ & & $\mathrm{H}$ & 1.7 & 5.770 \\
\hline 71 & & $\mathrm{H}$ & $\mathrm{H}$ & $\mathrm{OH}$ & $\mathrm{H}$ & 1.6 & 5.796 \\
\hline 72 & & $\mathrm{H}$ & $\mathrm{H}$ & & $\mathrm{CH}_{3}$ & 0.66 & 6.180 \\
\hline 73 & & $\mathrm{H}$ & $\mathrm{H}$ & & $\mathrm{CH}_{3}$ & 0.41 & 6.387 \\
\hline $74^{*}$ & & $\mathrm{CH}_{3}$ & $\mathrm{H}$ & & $\mathrm{H}$ & 0.79 & 6.102 \\
\hline 75 * & & $\mathrm{CH}_{3}$ & $\mathrm{H}$ & & $\mathrm{H}$ & 1.2 & 5.921 \\
\hline 76 & & $\mathrm{H}$ & $\mathrm{H}$ & & $\mathrm{H}$ & 4.0 & 5.398 \\
\hline 77 & & $\mathrm{H}$ & $\mathrm{H}$ & & F & 0.45 & 6.347 \\
\hline 78 * & & $\mathrm{H}$ & $\mathrm{H}$ & & F & 0.46 & 6.337 \\
\hline
\end{tabular}


Table 3. Cont.

\begin{tabular}{|c|c|c|c|c|c|c|c|}
\hline Mol. & $\mathbf{R}_{\mathbf{1}}$ & $\mathbf{R}_{2}$ & $\mathbf{R}_{3}$ & $\mathbf{R}_{\mathbf{4}}$ & $\mathbf{R}_{6}$ & $\mathrm{IC}_{50}(\mathrm{nM})$ & $\mathrm{pIC}_{50}$ \\
\hline 79 & & $\mathrm{H}$ & $\mathrm{H}$ & & F & 0.22 & 6.658 \\
\hline 80 & & $\mathrm{H}$ & $\mathrm{H}$ & & F & 0.77 & 6.114 \\
\hline 81 & & $\mathrm{H}$ & $\mathrm{H}$ & & F & 0.48 & 6.319 \\
\hline $82 *$ & & $\mathrm{H}$ & $\mathrm{H}$ & & F & 0.35 & 6.456 \\
\hline 83 & & $\mathrm{H}$ & $\mathrm{H}$ & & F & 0.59 & 6.229 \\
\hline $84^{*}$ & & $\mathrm{H}$ & $\mathrm{H}$ & & F & 0.32 & 6.495 \\
\hline 85 & & $\mathrm{H}$ & $\mathrm{H}$ & & $\mathrm{CN}$ & 1.0 & 6.000 \\
\hline 86 & & $\mathrm{H}$ & $\mathrm{H}$ & & $\mathrm{CN}$ & 0.49 & 6.310 \\
\hline 87 * & & $\mathrm{H}$ & $\mathrm{H}$ & & $\mathrm{Cl}$ & 0.25 & 6.602 \\
\hline 88 * & & $\mathrm{H}$ & $\mathrm{H}$ & & $\mathrm{Cl}$ & 1.0 & 6.000 \\
\hline 89 & & $\mathrm{H}$ & $\mathrm{H}$ & & $\mathrm{Cl}$ & 1.3 & 5.886 \\
\hline 90 & & $\mathrm{H}$ & $\mathrm{H}$ & & $\mathrm{Cl}$ & 0.81 & 6.092 \\
\hline
\end{tabular}


Table 3. Cont.

\begin{tabular}{|c|c|c|c|c|c|c|c|}
\hline Mol. & $\mathbf{R}_{1}$ & $\mathbf{R}_{2}$ & $\mathbf{R}_{3}$ & $\mathbf{R}_{4}$ & $\mathbf{R}_{6}$ & $\mathrm{IC}_{50}(\mathrm{nM})$ & $\mathrm{pIC}_{50}$ \\
\hline $91 *$ & & $\mathrm{H}$ & $\mathrm{H}$ & & $\mathrm{Cl}$ & 0.62 & 6.208 \\
\hline 92 & & $\mathrm{H}$ & $\mathrm{H}$ & & $\mathrm{Cl}$ & 0.44 & 6.357 \\
\hline 93 & & $\mathrm{H}$ & $\mathrm{H}$ & & $\mathrm{Cl}$ & 0.55 & 6.260 \\
\hline 94 & & $\mathrm{H}$ & $\mathrm{H}$ & & $\mathrm{Cl}$ & 0.85 & 6.071 \\
\hline 95 & & $\mathrm{H}$ & $\mathrm{H}$ & & $\mathrm{Cl}$ & 0.91 & 6.041 \\
\hline 96 & & $\mathrm{H}$ & $\mathrm{H}$ & & $\mathrm{Cl}$ & 1.0 & 6.000 \\
\hline 97 & & $\mathrm{H}$ & $\mathrm{H}$ & & $\mathrm{H}$ & 0.9 & 6.046 \\
\hline 98 & & $\mathrm{H}$ & $\mathrm{H}$ & & $\mathrm{Cl}$ & 2.0 & 5.699 \\
\hline 99 & & $\mathrm{H}$ & $\mathrm{H}$ & & $\mathrm{Cl}$ & 0.45 & 6.347 \\
\hline 100 & & $\mathrm{H}$ & $\mathrm{H}$ & & F & 0.35 & 6.456 \\
\hline 101 * & $\mathrm{H}$ & $\mathrm{H}$ & & $\mathrm{H}$ & & 189 & 3.724 \\
\hline 102 * & $\mathrm{H}$ & $\mathrm{H}$ & & $\mathrm{H}$ & & 308 & 3.511 \\
\hline 103 * & $\mathrm{H}$ & $\mathrm{H}$ & & $\mathrm{H}$ & & 461 & 3.336 \\
\hline
\end{tabular}


Table 3. Cont.

\begin{tabular}{|c|c|c|c|c|c|c|c|}
\hline Mol. & $\mathbf{R}_{1}$ & $\mathbf{R}_{2}$ & $\mathbf{R}_{3}$ & $\mathbf{R}_{4}$ & $\mathbf{R}_{6}$ & $\mathrm{IC}_{50}(\mathrm{nM})$ & $\mathrm{pIC}_{50}$ \\
\hline 104 * & $\mathrm{H}$ & $\mathrm{H}$ & & $\mathrm{H}$ & & 110 & 3.959 \\
\hline 105 & $\mathrm{H}$ & $\mathrm{H}$ & & $\mathrm{H}$ & & 28 & 4.553 \\
\hline 106 * & $\mathrm{H}$ & $\mathrm{H}$ & & $\mathrm{H}$ & & 88 & 4.056 \\
\hline 107 * & $\mathrm{H}$ & $\mathrm{H}$ & $\mathrm{H}$ & & & 379 & 3.421 \\
\hline 108 & $\mathrm{H}$ & $\mathrm{H}$ & $\mathrm{H}$ & & & 15 & 4.824 \\
\hline 109 & $\mathrm{H}$ & $\mathrm{H}$ & $\mathrm{H}$ & & & 32 & 4.495 \\
\hline 110 & $\mathrm{H}$ & $\mathrm{H}$ & $\mathrm{H}$ & & & 24 & 4.620 \\
\hline 111 & $\mathrm{H}$ & $\mathrm{H}$ & $\mathrm{H}$ & & & 71 & 4.149 \\
\hline 112 & $\mathrm{H}$ & $\mathrm{H}$ & $\mathrm{H}$ & & & 59 & 4.229 \\
\hline 113 & $\mathrm{H}$ & $\mathrm{H}$ & $\mathrm{H}$ & & & 103 & 3.987 \\
\hline 114 * & $\mathrm{H}$ & $\mathrm{H}$ & $\mathrm{H}$ & & & 44 & 4.357 \\
\hline 115 * & $\mathrm{H}$ & $\mathrm{H}$ & $\mathrm{H}$ & & & 127 & 3.896 \\
\hline 116 * & $\mathrm{H}$ & $\mathrm{H}$ & $\mathrm{H}$ & & & 101 & 3.996 \\
\hline 117 & $\mathrm{H}$ & $\mathrm{H}$ & $\mathrm{H}$ & & & 19 & 4.721 \\
\hline 118 * & $\mathrm{H}$ & $\mathrm{H}$ & $\mathrm{H}$ & & & 22 & 4.658 \\
\hline
\end{tabular}


Table 3. Cont.

\begin{tabular}{|c|c|c|c|c|c|c|c|}
\hline Mol. & $\mathbf{R}_{\mathbf{1}}$ & $\mathbf{R}_{2}$ & $\mathbf{R}_{3}$ & $\mathbf{R}_{4}$ & $\mathbf{R}_{6}$ & $\mathrm{IC}_{50}(\mathrm{nM})$ & $\mathrm{pIC}_{50}$ \\
\hline 119 & $\mathrm{H}$ & $\mathrm{H}$ & $\mathrm{H}$ & & & 16 & 4.796 \\
\hline $120 *$ & $\mathrm{H}$ & $\mathrm{H}$ & $\mathrm{H}$ & & & 12 & 4.921 \\
\hline 121 & & $\mathrm{H}$ & $\mathrm{H}$ & & $\mathrm{H}$ & 16 & 4.796 \\
\hline 122 & & $\mathrm{H}$ & $\mathrm{H}$ & & $\mathrm{H}$ & 15 & 4.824 \\
\hline 123 & & $\mathrm{H}$ & $\mathrm{H}$ & & $\mathrm{H}$ & 16 & 4.796 \\
\hline 124 & & $\mathrm{H}$ & $\mathrm{H}$ & & $\mathrm{H}$ & 17 & 4.770 \\
\hline 125 & & $\mathrm{H}$ & $\mathrm{H}$ & & $\mathrm{H}$ & 16 & 4.796 \\
\hline 126 * & & $\mathrm{H}$ & $\mathrm{H}$ & & $\mathrm{H}$ & 16 & 4.796 \\
\hline 127 * & & $\mathrm{H}$ & $\mathrm{H}$ & & $\mathrm{H}$ & 390 & 3.409 \\
\hline 128 * & & $\mathrm{H}$ & $\mathrm{H}$ & & $\mathrm{H}$ & 15 & 4.824 \\
\hline 129 & & $\mathrm{H}$ & $\mathrm{H}$ & & $\mathrm{H}$ & 0.4 & 6.398 \\
\hline 130 & & $\mathrm{H}$ & $\mathrm{H}$ & & $\mathrm{Cl}$ & 0.90 & 6.046 \\
\hline 131 & & $\mathrm{H}$ & $\mathrm{H}$ & & $\mathrm{Cl}$ & 1.0 & 6.000 \\
\hline 132 & & $\mathrm{H}$ & $\mathrm{H}$ & & F & 0.34 & 6.585 \\
\hline
\end{tabular}




\subsection{Preparation of Protein}

The crystal structure of BTK with high resolution was retrieved from the protein data bank (PDB ID: 5JRS) [20]. This crystal structure was prepared using a protein preparation module in Sybyl-X 2.0. Ligand and water molecules were removed. Furthermore, polar hydrogen atoms were added for investigating interactions between inhibitors and BTK.

\subsection{Molecular Docking and Alignment}

The molecular dockings of 1-132 were performed using Surflex-Dock (SFXC) module with default parameters, except that the maximum number of per molecular conformation was defined as 40 to ensure that the docked conformations in the BTKBTK-binding site were reasonable. The rational docked conformations of the compound in the protein-binding site were picked up from the clustered docking poses according to the principle of low energy and rational conformation [28]. The most potent compound, $\mathbf{7 9}$, with the rational conformation possessing the lowest energy, was chosen as the reference molecule. Rational conformations of the remaining inhibitors in the dataset based on the interactions with the BTK-enzyme-binding site were aligned on the common substructure of the reference compound (Figure 8). After the conformations were aligned in the BTKBTK-binding site, all selected conformations were conserved as a database file, which was used for 3D-QSAR study.

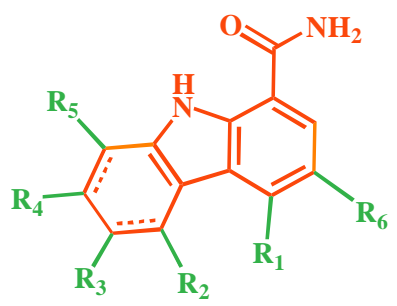

Figure 8. The common scaffold of the dataset.

\subsection{D-QSAR Analysis Studies}

3D-QSAR analyses performed by the QSAR command bar of SYBYL X-2.0 (Tripos (DE), Inc., St. Louis, MO, USA) were carried out in the form of molecular spreadsheets to create CoMFA and CoMSIA fields from the database file acquired after molecular docking. The CoMFA [17] fields, including steric (S) and electrostatic (E) fields, were calculated under default settings with energy cutoff values of $30 \mathrm{kcal} / \mathrm{mol}$. With the exception of the same fields in CoMFA, the CoMSIA [18] fields also containing hydrophobic $(\mathrm{H})$ and hydrogen-bond donor $(\mathrm{D})$ and acceptor $(\mathrm{A})$ fields were derived using the same method as that of the CoMFA calculations. Both CoMFA and CoMSIA analyses were calculated in the standard settings with an attenuation factor $\alpha$ of 0.3. After 3D-QSAR analyses, the standard contour maps for both CoMFA and CoMSIA to visualize the results were developed using the field type StDev*Coeff.

\subsection{Model Validation}

All the developed CoMFA and CoMSIA models were checked for stability and robustness using the internal and external test set validations. Internal validation was carried out using a PLS [29] approach of cross-validation method to inspect the predictability of the dataset. The external test set containing 32 molecules not included in the model building was applied to verify the accuracy of the predictive abilities of the derived 3D-QSAR models. In the PLS approach, leave-one-out (LOO) method analysis generated the cross-validated $\mathrm{q}^{2}$ and the optimum number of components. The final CoMFA and CoMSIA models were developed using the obtained optimal number of components without cross-validation analysis. When the values of the coefficients fall between 1.0 and 0.5 [30], an accurate model is accepted. Furthermore, for better evaluation of the accuracy and robustness of the 
developed models, non-cross-validation analysis was employed to yield the conventional correlation coefficient $r^{2}$ and the $F$-test value $(F)$.

\section{Conclusions}

A 3D-QSAR study on carbazole inhibitors based on a common scaffold was conducted with the generation of rational docking conformations and CoMFA/CoMSIA models. The reasonable CoMFA $\left(q^{2}=0.761, r^{2}=0.933\right)$ and CoMSIA $\left(q^{2}=0.891, r^{2}=0.988\right)$ models displayed satisfactory correlations and predictive abilities. CoMFA and CoMSIA contour maps provided information (shown in Figure 9) indicating that structural optimization for improving activities can be predominantly considered by adding bulky negative electrostatic groups and hydrophilic groups at $R_{1}$, by increasing hydrophilic groups at $\mathrm{R}_{4}$, and by raising $\mathrm{H}$-bond donor and acceptor substituents at 1-position. Moreover, the predicted ability of 3D-QSAR models was validated for application in predicting the activities of newly designed compounds and further provided a valuable clue in the design of novel carbazole inhibitors for RA treatment.

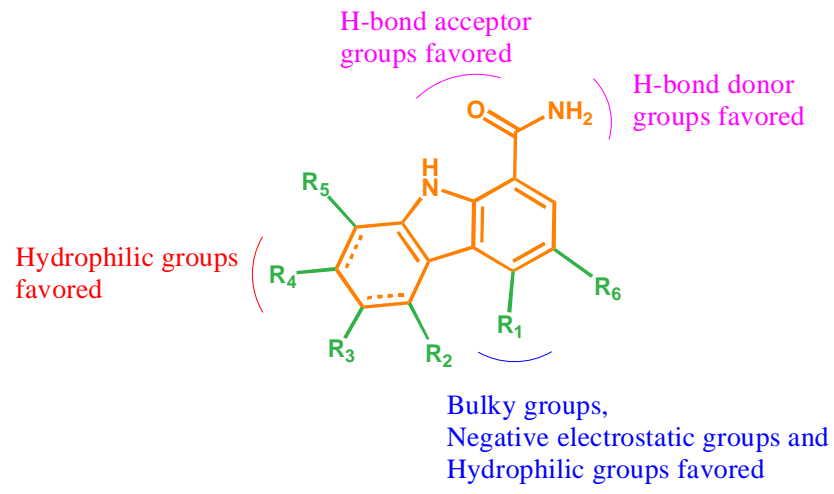

Figure 9. The structure-activity relationship (SAR) summarized based on our work.

Acknowledgments: This work was supported by a grant from the National Natural Science Foundation of China (81202389).

Author Contributions: Rui Li and Yongli Du conceived and designed the experiments; Rui Li performed the experiments; Rui Li and Zhipei Gao analyzed the data; Jingkang Shen contributed materials tools; Rui Li wrote the paper.

Conflicts of Interest: There are no conflicts of interest to declare.

\section{Abbreviations}

$\begin{array}{ll}\text { BTK } & \text { Broton's tyrosine kinase } \\ \text { RA } & \text { Rheumatoid Arthritis } \\ \text { BCR } & \text { B-cell receptor } \\ \text { NSAIDs } & \text { non-steroidal anti-inflammatory drug } \\ \text { SAARDs } & \text { slow acting anti-rheumatic drugs } \\ \text { DMARDs } & \text { disease-modifying anti rheumatic drugs } \\ \text { 3D-QSAR } & \text { three-dimensional quantitative structure-activity relationship } \\ \text { CoMFA } & \text { comparative molecular field analysis } \\ \text { CoMSIA } & \text { comparative molecular similarity indices analysis } \\ \text { PLS } & \text { partial least square } \\ \text { XLA } & \text { X-linked agammaglobulinemia } \\ \text { ALL } & \text { acute lymphoblastic leukemia } \\ \text { CML } & \text { chronic myeloid leukemia } \\ \text { CLL } & \text { chronic lymphocytic leukemia }\end{array}$




\section{References}

1. Shaw, M.; Collins, B.F.; Ho, L.A.; Raghu, G. Rheumatoid arthritis-associated lung disease. Eur. Respir. Rev. 2015, 24, 1-16. [CrossRef] [PubMed]

2. Brito, Y.; Glassberg, M.K.; Ascherman, D.P. Rheumatoid Arthritis-Associated Interstitial Lung Disease: Current Concepts. Curr. Rheumatol. Rep. 2017, 19, 79. [CrossRef] [PubMed]

3. Smolen, J.S.; Landewe, R.; Breedveld, F.C.; Dougados, M.; Emery, P.; Gaujoux-Viala, C.; Gorter, S.; Knevel, R.; Nam, J.; Schoels, M.; et al. EULAR recommendations for the management of rheumatoid arthritis with synthetic and biological disease-modifying antirheumatic drugs. Ann Rheum. Dis. 2010, 69, 964-975. [CrossRef] [PubMed]

4. Ma, M.H.; Cope, A.P.; Scott, D.L. Safety of combination therapies in early rheumatoid arthritis: A systematic comparison between antirheumatic drugs and TNF inhibitors with methotrexate. Int. J. Clin. Rheumatol. 2010, 5, 547-554. [CrossRef]

5. Takata, M.; Kurosaki, T. A Role for Bruton's Tyrosine Kinase in B Cell Antigen Receptor-mediated Activation of Phospholipase C-gamma 2. J. Exp. Med. 1996, 184, 31-40. [CrossRef] [PubMed]

6. Mohamed, A.J.; Nore, B.F.; Christensson, B.; Smith, C.I. Signalling of Bruton's Tyrosine Kinase, Btk. Scand. J. Immunol. 1999, 49, 113-118. [CrossRef] [PubMed]

7. Whang, J.A.; Chang, B.Y. Bruton's tyrosine kinase inhibitors for the treatment of rheumatoid arthritis. Drug Discov. Today 2014, 19, 1200-1204. [CrossRef] [PubMed]

8. Pan, Z.; Scheerens, H.; Li, S.J.; Schultz, B.E.; Sprengeler, P.A.; Burrill, L.C.; Mendonca, R.V.; Sweeney, M.D.; Scott, K.C.; Grothaus, P.G.; et al. Discovery of selective irreversible inhibitors for Bruton's tyrosine kinase. ChemMedChem 2007, 2, 58-61. [CrossRef] [PubMed]

9. Honigberg, L.A.; Smith, A.M.; Sirisawad, M.; Verner, E.; Loury, D.; Chang, B.; Li, S.; Pan, Z.; Thamm, D.H.; Miller, R.A.; et al. The Bruton tyrosine kinase inhibitor PCI-32765 blocks B-cell activation and is efficacious in models of autoimmune disease and B-cell malignancy. Proc. Natl. Acad. Sci. USA 2010, 107, 13075-13080. [CrossRef] [PubMed]

10. Wu, J.; Zhang, M.; Liu, D. Acalabrutinib (ACP-196): A selective second-generation BTK inhibitor. J. Hematol. Oncol. 2016, 9, 21. [CrossRef] [PubMed]

11. Yoshizawa, T.; Birkett, J.T.; Kawabata, K. ONO-4059, A Novel Bruton's Tyrosine Kinase (Btk) Inhibitor: Synergistic Activity in Combination with Chemotherapy in a ABC-DLBCL Cell Line. Blood 2013, $122,5151$.

12. Evans, E.K.; Tester, R.; Aslanian, S.; Karp, R.; Sheets, M.; Labenski, M.T.; Witowski, S.R.; Lounsbury, H.; Chaturvedi, P.; Mazdiyasni, H.; et al. Inhibition of Btk with CC-292 provides early pharmacodynamic assessment of activity in mice and humans. J. Pharmacol. Exp. Ther. 2013, 346, 219-228. [CrossRef] [PubMed]

13. Park, J.K.; Byun, J.Y.; Park, J.A.; Kim, Y.Y.; Lee, Y.J.; Oh, J.I.; Jang, S.Y.; Kim, Y.H.; Song, Y.W.; Son, J.; et al. HM71224, a novel Bruton's tyrosine kinase inhibitor, suppresses B cell and monocyte activation and ameliorates arthritis in a mouse model: A potential drug for rheumatoid arthritis. Arthritis Res. Ther. 2016, 18, 91. [CrossRef] [PubMed]

14. Watterson, S.H.; De Lucca, G.V.; Shi, Q.; Langevine, C.M.; Liu, Q.; Batt, D.G.; Beaudoin Bertrand, M.; Gong, H.; Dai, J.; Yip, S.; et al. Discovery of 6-Fluoro-5-(R)-(3-(S)-(8-fluoro-1-methyl-2,4-dioxo-1,2dihydroquinazolin-3(4H)-yl)-2-methylphenyl)-2-(S)-(2-hydroxypropan-2-yl)-2,3,4,9-tetrahydro-1H-carbazole8-carboxamide (BMS-986142): A Reversible Inhibitor of Bruton's Tyrosine Kinase (BTK) Conformationally Constrained by Two Locked Atropisomers. J. Med. Chem. 2016, 59, 9173-9200. [CrossRef] [PubMed]

15. Lee, S.K.; Xing, J.; Catlett, I.M.; Adamczyk, R.; Griffies, A.; Liu, A.; Murthy, B.; Nowak, M. Safety, pharmacokinetics, and pharmacodynamics of BMS-986142, a novel reversible BTK inhibitor, in healthy participants. Eur. J. Clin. Pharmacol. 2017, 73, 689-698. [CrossRef] [PubMed]

16. Gillooly, K.M.; Pulicicchio, C.; Pattoli, M.A.; Cheng, L.; Skala, S.; Heimrich, E.M.; McIntyre, K.W.; Taylor, T.L.; Kukral, D.W.; Dudhgaonkar, S.; et al. Bruton's tyrosine kinase inhibitor BMS-986142 in experimental models of rheumatoid arthritis enhances efficacy of agents representing clinical standard-of-care. PLoS ONE 2017, 12, e0181782. [CrossRef] [PubMed]

17. Cramer, R.D.; Patterson, D.E.; Bunce, J.D. Comparative molecular field analysis (CoMFA). 1. Effect of shape on binding of steroids to carrier proteins. J. Am. Chem. Soc. 1988, 110, 5959-5967. [CrossRef] [PubMed] 
18. Klebe, G.; Abraham, U.; Mietzner, T. Molecular Similarity Indices in a Comparative Analysis (CoMSIA) of Drug Molecules to Correlate and Predict Their Biological Activity. J. Med. Chem. 1994, 37, 4130-4146. [CrossRef] [PubMed]

19. Li, X.; Zuo, Y.; Tang, G.; Wang, Y.; Zhou, Y.; Wang, X.; Guo, T.; Xia, M.; Ding, N.; Pan, Z. Discovery of a series of 2,5-diaminopyrimidine covalent irreversible inhibitors of Bruton's tyrosine kinase with in vivo antitumor activity. J. Med. Chem. 2014, 57, 5112-5128. [CrossRef] [PubMed]

20. De Lucca, G.V.; Shi, Q.; Liu, Q.; Batt, D.G.; Beaudoin Bertrand, M.; Rampulla, R.; Mathur, A.; Discenza, L.; D'Arienzo, C.; Dai, J.; et al. Small Molecule Reversible Inhibitors of Bruton's Tyrosine Kinase (BTK): Structure-Activity Relationships Leading to the Identification of 7-(2-Hydroxypropan-2-yl)-4-[2-methyl3-(4-oxo-3,4-dihydroquinazolin-3-yl)phenyl]-9H-carbazole-1-carboxamide (BMS-935177). J. Med. Chem. 2016, 59, 7915-7935. [CrossRef] [PubMed]

21. Liu, Q.; Batt, D.G.; Lippy, J.S.; Surti, N.; Tebben, A.J.; Muckelbauer, J.K.; Chen, L.; An, Y.; Chang, C.; Pokross, M.; et al. Design and synthesis of carbazole carboxamides as promising inhibitors of Bruton's tyrosine kinase (BTK) and Janus kinase 2 (JAK2). Bioorg. Med. Chem. Lett. 2015, 25, 4265-4269. [CrossRef] [PubMed]

22. Liu, Q.; Batt, D.G.; DeLucca, G.V.; Shi, Q.; Tebben, A.J. Carbazole Carboxamide Compounds Useful as Kinase Inhibitors. U.S. Patent 8,362,065, 9 January 2013.

23. Batt, D.G.; Bertrand, M.B.; DeLucca, G.; Galella, M.A.; Ko, S.S.; Langevine, C.M.; Liu, Q.; Shi, Q.; Srivastava, A.S.; Tino, J.A.; et al. Substituted Tetrahydrocarbazole and Carbazole Carboxamide Compounds. U.S. Patent 9,334,290, 10 May 2016.

24. Clark, M.; Cramer, R.D.; Van Opdenbosch, N. Validation of the General Purpose Tripos 5.2 Force Field. J. Comput. Chem. 1989, 10, 982-1012. [CrossRef]

25. Cramer, R.D., III; Patterson, D.E.; Bunce, J.D. Recent advances in comparative molecular field analysis (CoMFA). Prog. Clin. Biol. Res. 1989, 291, 161-165. [PubMed]

26. Balasubramanian, P.K.; Balupuri, A.; Gadhe, C.G.; Cho, S.J. 3D QSAR modeling study on 7-aminofuro [2,3-c] pyridine derivatives as TAK1 inhibitors using CoMFA and COMSIA. Med. Chem. Res. 2014, 24, 2347-2365. [CrossRef]

27. Cai, B.Q.; Jin, H.X.; Yan, X.J.; Zhu, P.; Hu, G.X. 3D-QSAR and 3D-QSSR studies of thieno[2,3-d]pyrimidin-4-yl hydrazone analogues as CDK4 inhibitors by CoMFA analysis. Acta Pharmacol. Sin. 2014, 35, 151-160. [CrossRef] [PubMed]

28. Aalizadeh, R.; Pourbasheer, E.; Ganjali, M.R. Analysis of B-Raf V600E inhibitors using 2D and 3D-QSAR, molecular docking and pharmacophore studies. Mol. Divers. 2015, 19, 915-930. [CrossRef] [PubMed]

29. Wold, S.; Ruhe, A.; Wold, H.; Dunn, W.J. The collinearity problem in linear regression. The partial least squares (PLS) approach to generalized inverses. SIAM J. Sci. Stat. Comput. 1984, 5, 735-743. [CrossRef]

30. Wehrens, R.; Putter, H.; Buydens, L.M. The bootstrap: A tutorial. Chemometr. Intell. Lab. Syst. 2000, 54, 35-52. [CrossRef]

(C) 2018 by the authors. Licensee MDPI, Basel, Switzerland. This article is an open access article distributed under the terms and conditions of the Creative Commons Attribution (CC BY) license (http:// creativecommons.org/licenses/by/4.0/). 